\title{
Constructing the Cinema-of-Intent: Revisiting Hatta Azad Khan's 'True Picture'
}

\author{
Badrul Redzuan Abu Hassan \\ School of Media and Communication Studies \\ National University of Malaysia, Bangi UKM 43600, Selangor, Malaysia \\ Tel: 60-3-8921-5811 E-mail: badrulrah@gmail.com
}

Received: February 20, 2012

Accepted: March 13, 2012 Published: April 16, 2012

doi:10.5539/ass.v8n5p55

URL: http://dx.doi.org/10.5539/ass.v8n5p55

\begin{abstract}
One of the most important works on Malaysian cinema of the last twenty years has been Hatta Azad Khan's The Malay Cinema (1997). Khan's seminal work is located within the critical debates on the notion of national cinema that preoccupied film scholars, predominantly in the West, from the mid 1980s through the 1990s. Comparatively, Khan's conceptualization is juxtaposed in this article for a critical appraisal between the influential Australian and British cinema contexts, as both are forms of national cinemas in their own rights. This article then revisits Khan's scholarship on Malay cinema, particularly the factors shaping his 'true picture' idealism in the context of emerging Malaysian cinema in terms of it as a developmental and critical sphere of cosmopolitan aesthetics. Finally, this article will evaluate Khan's belief in the relevance of social realism as a philosophical interpretation for an ideologically driven cinema-of-intent and whether or not it can serve as a framework for the future of Malaysian cinema.
\end{abstract}

Keywords: National cinema, Malay cinema, Cinema-of-intent, Social realism, True picture

\section{Introduction}

One of the most important works on Malaysian cinema of the last twenty years has been Hatta Azad Khan's The Malay Cinema (1997). Khan's seminal work is located within debates on the notion of national cinema that preoccupied film scholars, predominantly in the West, from the mid 1980s through the 1990s. This article attempts to revisit Khan's scholarship on Malay cinema, particularly the relevance of his 'true picture' idealism within the context of Malaysian cinema as a developmental and critical sphere of cosmopolitan aesthetics. In particular, it seeks to explore Khan's belief in the virtue of social realism as the germ of a philosophical interpretation of the direction of what is regarded today an emergent national film industry. In terms of relevance, harking back to Khan's treatise appears sensible as the apparent sociocultural and political consciousness of the zeitgeist and their deployment in creative spaces has become increasingly palpable in contemporary Malaysian films.

Khan's study of the Malay film industry in the 80 s and early 90s, can now assume its position as the foundational critique of Malaysian, beyond its traditional realm of Malay cinema. This is undertaken by exploring Khan's notion of a 'sociocultural turn' in Malay cinema. That the film industry today demonstrably displays its inherently emergent and hybrid nature of aesthetic and critical discourses marks Khan's anticipation rather prophetic if inevitable. Yet, although an established filmmaker in his own right, Khan's intellectual thoughts, however, continues or seems to elude the critical reception which it deserves today. Thus, this article attempts to revisit the critical and developmental premise of Khan's philosophy in The Malay Cinema by engaging in a range of comparative and inter textual mode of 'conversations' with cultural theorists, national cinemas and of course, films.

Indeed, for Khan, social criticism has been his philosophical practice ever since he and other student activist-cum-playwrights began writing and directing absurdist and satirical works for the reactionary 'angry young men' theatre in the 1970s, as part of a concerted anti-establishment, anti-authoritarian movement which culminated in the 1974 Baling Famine Protest. (Note1). Khan's experimental stage-plays, Puteri Gunung Ledang and Jebat, were written as critiques of Malay feudalism, embedded in contemporary themes, role-reversals and 
stream of consciousness of the anti-hero that provide defamiliarising but refreshing counter-perspectives. Khan's more subtle, comic and witty criticism against systemic forms of corruption in the Malaysian bureaucracy plaguing the quotidian life of the city's slum-dwellers can be found in Syyy!, (1987), then renamed Pi Mai Pi Mai Tang $T u$ by the filmmaker Hafsham, and institutionalized itself as the highest rating and longest running Malaysian sitcom for eighteen years on TV3, a private broadcasting station. Interestingly, Khan's Kampung Baharu Musical Theatre (2011) joins the fray of vorpal ? articulation against the 'transformation' plan of Kampung Baharu, the last remaining Malay settlement in the capital city by ostensibly liberal capitalism, in the name of Malay development and empowerment. There is a sense that Khan has shifted his critical and creative energies towards cultural identity and cultural maintenance through his self-written and self-directed film, Wayang (Shadow Play, 2008). Besides portraying the lonely struggle of the resilient traditional artist - the master puppeteer - plying his trade in the Malay heartland against religious and various forms of adverse ideological opposition, the award-winning Wayang has also taken social realist themes of Malaysian cinema to a more global perspective. Although Khan directed only two films, the other being Mat Som (1990), a film adaptation of the popular cartoon book Mat Som the Kampong Boy (1990) by Lat, for some reasons, however, these films do not quite translate the enthusiasm which he demonstrated in his The Malay Cinema. For Khan, Malaysian cinema should ideally be framed within the overlapping terrains of history, politics and culture, and hence, his admiration for films such as Antara Dua Darjat (1960) and Hang Jebat (1961) and filmmakers like P. Ramlee and Hussein Haniff, who attempted "to portray the actual truth about the social issues in a much bigger dimension" (189).

\section{Defining 'National Cinema'}

Khan's research attempts to validate the argument that "interational [c]cinema is a cinema of small nations and is of recent emergence" (1997:11). He puts forward the case of Malaysian national cinema under the theoretical lens at a time when "national film industries of most countries of East and Southeast Asia [were] virtually unknown in the West" (11). Khan's work does not consciously situate Malaysian cinema 'under the western gaze', as it were, but is considered seminal in relation to it being a part of the globalizing challenge to Hollywood hegemony which dominates the global imaginary. As Khan puts it, the notion of 'true picture' is an attempt to "establish not only films with local form and content but also to develop a style and idioms different from that of mainstream Hollywood" (12). It shall become clearer that this true picture is the platform for the construction of the ideal cinema, the cinema-of-intent, for the Malaysian national cinema as envisaged by a sophisticated intellectual-filmmaker such as Khan. But first, it is essential to revisit some of the key arguments on national cinema which were formed around the same time that Khan's 'true picture' was being conceptualized before becoming another rejoinder to the respected global dialogue.

For Paul Willemen (1992:146), "national cinema is a cinema that addresses - directly or indirectly, and regardless of who pays the bills - the specific socio-historical configurations obtaining within nation-states. This means that national cinema must be able to engage with cultural and historical specificities". Andrew Higson (1989:36), however, has suggested two perspectives, economic and textual, to the definition of any national cinema. The economic perspective links national cinema with questions like "where are these films made, and by whom? Who owns and controls the industrial infrastructures, the production companies, the distributors and the exhibition circuits?. While the textual approach is interested in questions like "what are these films about? Do they share a common style or worldview? To what extent are they engaged in 'exploring, questioning and constructing a notion of nationhood in the films themselves and in the consciousness of the viewer?'. Not to be excluded, Khan somewhat offers a simple definition, that is, "a cinema which is the product of a particular nation, portraying the life and conflicts of its people, speaking in their own language and using their own country as the background" (1997:20). Such a 'working' definition is noticeably puritan; its tonality is derived, quite obviously, along the familiar idioms of the country's constitution, hence, explicitly nationalistic.

But at this point, it is quite important to make one thing quite clear about Khan's formulation, and that is he did not relate his 'true picture' conceptually to any theoretical framework on national cinema in the West in the early 90s. This seems to suggest, rather strongly, that his notion of 'true picture' is merely calibrated from his exposure to the commentaries by James Monaco and to some extent, David Hanan, on the impact of social realism both in the films of acclaimed Polish director, Andrzej Wajda and Indonesia's Teguh Karya. Whilst these filmmakers were influential to him, Khan's conception of the 'true picture' philosophy in actual fact, had probably sidestepped the more if not the most significant post-colonialist discourses of resistance, identity and sovereignty at the time, against the global dominance of Hollywood. It is a conspicuous absence indeed in his scholarship but what is more important is the fact that Khan's Malay Cinema, arguably, is a study that shares interesting discursive parallels, both critical and historical, with respect to certain arguments that arose in British 
and Australian cinema discourses between late 1980s and early 1990s. It is perhaps worthy to further explore these respective discourses comparatively since they were inherently motivated by nationalistic arguments, which all but reflecting the postcolonial modes of resistance against the cultural imperialism of Hollywood cinema. By virtue of being a foil, the following discussion will explore two theoretical models of national cinema or more precisely, cinema-of-intent (read the ideal cinema), against Khan's critique of his own deeply ethno-nationalistic film culture.

\section{Cinema-of-Intent 1: Exploring the British Model}

The first context locates Khan's critical inquiry on the cultural identity of national cinema as similar to that of Andrew Higson for British cinema. Through his seminal article, The concept of national cinema (1989), Higson proposes a nationalistic "inward looking" (42) definition of "films produced within a particular nation-state" (36) and it is often regarded as the general point of embarkation on the discourse of national cinema. According to Higson, an "inward-looking" approach may be used to define a national cinema "in terms of its relationship to an already existing national political, economic and cultural identity (in so far as a singular coherent identity can be established) and set of traditions" (42), rather than by contrasting one national cinema with another. For Higson, "British cinema would be defined in terms of already established discourses of Britishness, by turning in on itself, on its own history and cultural formation, and the defining ideologies of national identity and nationhood, rather than by reference to other national cinemas" (ibid.).

Despite it being exclusively based on the British cinema context, Higson's concept appears useful to illustrate the construction of Malay cinema as a nationally-defined cultural institution that has been privileged, thus far, by Malay hegemonic power enshrined in the Federal Constitution of Malaysia. In actual fact, Malay cinema finds its 'rightful' place within the ambit of the omnipotent Article Number 153 of the Constitution which "safeguard[s] the special position of the Malays". (Note 2). Though it seems almost impossible to challenge the status quo of Malay cinema, it can still be strategically 'explored', a euphemism denoting Khan's 'disguised' but persuasive critical intervention in Malay cinema discourse. Any national cinema occupying a dominant status quo functions as a cultural articulation of a nation and therefore, should be 'safeguarded' from becoming dysfunctional or ambiguous - a key point which is both shared by Higson and Khan. Higson issues a set of critical questions about cultural representation in a national cinema:

The concern is with what the films are about. Do they share a common style or world view? Do they share common themes, motifs or preoccupations? How do they project the national character? How do they dramatise the fantasies of national identity? Are they concerned with the question of nationhood? What role do they play in constructing the sense or the image of the nation? (cited in Rayner, 2000:21-22).

There is remarkable similitude between the questions above and those of Khan's below:

In establishing a national cinema a film-maker will have to ask himself [sic] such as what is the relationship between cinema and national identity? Certain social aspects of a country and its people need to be clearly identified so that the issues and characterization will be in line with the country's identity. Another simple yet complex question is to ask what role cinema plays in the construction of nationhood. This is most important for a country with a multi-racial population like Malaysia. (Khan, 1997:49

What seems most noticeable above is the call to filmmakers to further 'explore' the cultural diversity and plurality of subjectivity to be the new underlying thrust of creative expressions for their work. This is precisely the objective of Khan's 'exploration' of the nationally-defined Malay cinema: to map a new terrain where socioculturally-situated practices of filmmaking and film spectatorship, arguably, can be more productive and meaningful. Effectively, Khan's newly constructed terrain is democratic and ethical as it attempts to establish the relation between national cinema and the country's multi-raciality.

Without doubt, Khan's "simple yet complex question" (ibid.) anticipates the pivotal role of national cinema in nation-building project through a candid but cosmopolitan cinematic imaginary. Here, Khan appears to implicate national cinema as having the ability to conceive a sense of nationhood to the multi-racial but fragmented Malaysian audience. In saying this, there was only a handful of Malay/sian films that could engage or 'speak to' the multi-racial audience in the early 1990s and it certainly would be factually wrong to claim that Khan's strategic 'exploration' had been stymied, if at all. The difference between Higson and Khan, as it were, in regards to fragmented multiraciality of film audience, would have been in the former's mobilizing of Benedict Anderson's (1987:7) "deep, horizontal comradeship" myth which "overlays the actual relations of a divided and fractured society (Wayne, 2002:25). Higson argues that "films will construct imaginary bonds which work to 
hold the peoples of a nation together as a community by dramatizing their current fears, anxieties, pleasures and aspirations" (cited in Higson, 2000:26).

Indeed, forging an imaginary likeness out of differences is commonsense and important to promote a national identity as long as the sociocultural diversity is not denied or repressed, particularly in a multiethnic, society like Malaysia operating within a majority-minority polity. In the case of Malay cinema, the representations of the Malays and Malayness against that of the non-Malays and their Otherness, may have been subtle, usually through cultural stereotyping but never deliberate, overbearing nor patronizing. The issue is that Malay cinema simply lacks the recognition of and identification with the national Other. As Khan admits in his study, "the situation for local Malay (Malaysian) national cinema is quite embarrassing considering that only a fraction of the Malays and a handful of Malaysians of other ethnic origins give their support" (212). In fact, Malay cinema might not have become 'national' if it had not become 'mainstream' and identifying itself with "official versions of national priorities, of which maintaining nation-state unity is key" (Chakravarty, 2000:224).

The importance of an engagement of a national cinema with its national cultural Other both as audience as well as narrative subject cannot be understated because it is anti-social, but because such national institution has seemingly allowed itself to be implicated, subtly or not, with purporting social injustice or cultural amnesia of the celluloid kind. This implication has resonance with Sumita S. Chakravarty's (2000:224) reservation that "the institution of narrative cinema in its mainstream forms may actually be resistant to nationalist imaginings, given that 'the nation' is always mediated by its 'fragments', that is, by individuals whose particularities of dress, speech and lifestyle locate them within specific regional, social and cultural configurations". Chakravarty contends that "because in dominant cinema the hero [or heroine] usually belongs to the majority community, his [or her] presence on screen renders invisible all those [O]thers whose incorporation into the national mainstream dominant cinema undertakes to bring about in the first place" (ibid.). Interestingly, Higson has revisited the 'imagined community' argument in his seminal work, and has claimed that it "sometimes seems unable to acknowledge the cultural difference and diversity that invariably marks both the inhabitants of a particular nation-state and the members of a more geographically dispersed 'national' communities" (Higson, 2000:66). This comment alludes to the tendency for national cinema "to focus only on those films that narrate the nation as just this finite, limited space, inhabited by a tightly coherent and unified community" (ibid.), a scenario that has some parallels with the state of Malay filmmaking and which Khan intends to reform.

\section{Cinema-of-Intent 2: Exploring the Australian Model}

The second context Khan's 'exploration' is located within a 'developmentalist' (read transformational) line of argument, in which the 're-invention' of Malay cinema is to be launched from "the intersection of economic and aesthetic criteria" - the locus of the "golden age" of Malay cinema of the Singapore studio era from 1955 to 1965 (Khan, 1997:89). A 'developmental' film culture would implicate a gradual shift from its ethno-nationalistic tendency towards an inclusive and pluralistic version of cultural nationalism that can accommodate a range of diverse cultural narratives and increasingly globalised subjectivities. A 'developmental' approach also underlines a national film industry's constant but necessary engagement with the "film as art vs. film as industry and commerce" (Rayner, 2000:7) dialectic. It is evident that The Malay Cinema is an interventionist work in an attempt, as it were, to swing the pendulum to its opposite, or to a certain direction if it had been erratic - which was actually the scenario during the era of 'the independents' and initial 'national support' in the 1970s and 1980s. Khan's philosophical intervention - although he is an accomplished filmmaker in his own right - signals a 'new' discourse of cultural nationalism in a postcolonial Malay/sian cinema after three decades national independence, a stance that resonates with revivalist discourses in Australian cinema in the 1990s.

Khan's knowledge of Australian cinema, derived mainly from Susan Dermody and Elizabeth Jacka's The screening of Australia. Vol. 2: Anatomy of a national cinema (1988), which he refers to in his conceptual discussion. It has been instructive for him, perhaps in two distinct realities. One, Australian and Malaysian cinema industries are vastly differentiated economically and culturally, hence, not on level grounds. The other, however, is the shared anxiety by these film industries on the impact of economic and cultural imperialism from Hollywood - which "travel effortlessly across national borders" (Higson, 2000:67) - on the development of film cultures which determines the formation of audiences, both popular and national, and film revenue. Unlike Malaysian cinema, however, the Australian film industry has established itself as a "second cinema" (Dermody and Jacka, 1988:24 in Khan, 1997:21) - an imitative model of the Hollywood film industry - and its well-documented commitment and capability to penetrate the American market is largely due to "the supportive and regulatory role of the state" (Dermody and Jacka, 1988:48 in O’Regan, 1996:13). In fact, as Mckenzie Wark (1995:202) asserts, "[w]ithout subsidy mechanism, there would be little chance of small countries retaining the 
ability to put home-grown stories and images on the screen". The government "economic intervention" was designed to develop Australian cinema as "the cultural flagship of the nation" (Turner, 1994a:202). It resulted in three decades of 'Australian film revival' as a national project, oscillating between "'discourses of nationalism' and 'discourses of commercialism"” (Dermody and Elizabeth Jacka, 1987:197), a dialectic inherent to film industry in small nations that might have some influence on Khan's 'exploration': the critical search for a national cinema identity.

Focussing on filmic 'discourses of nationalism' as critical "national self-expression", to quote Peter Weir (cited in Wimmer, 2007:103), Franz Kuna (1993:23 in Wimmer, 2007:92) has suggested that "[m]any Australian films show an almost "complete integration of Australian cultural perceptions (and obsessions) into a structured narrative' and they are always firmly anchored in the Australian myths, ideologues, landscapes and characters" found in well-known films such as Mad Max (1979), The Man from Snowy River (1982) and Crocodile Dundee (1986). But in contrast to the white, male, Anglo-Celtic 'common man' mythologizing of the 1980s, the Australian cinema of the 1990s "radically deviated from proven formulas, thus signaling more than a sheer boredom with the national identity trope" (Wimmer, 2007:104), as seen in Death in Brunswick (1990), Strictly Ballroom (1992) and Adventures of Priscilla, Queen of the Desert (1994).

Graeme Turner (1994b:34) has described this significant shift in Australian film culture as a "widespread renunciation of the traditional, European, notion of nationalism: as a social ideology built upon an expectation of cultural purity, of a people bound by a common religion, ethnicity, and cultural experience". According to him, the new ways of thinking about the nation is as "a political and cultural construction which must be more heterogeneous in its forms and practices"; "as constituted through elaborated patterns of difference as well as through constructions of unity" (ibid.). The challenge to the homogeneity of Australian nationhood from its own creative film industry in the 1990s has been regarded as the "cultural achievements" of the film revival although they are not as "easily quantifiable as economic achievements" (Turner, 1994a:203). The Australian cinema has been able to construct a progressive sense of national identity through a diverse range of genres that has "widened and multiplied" the "definitions of the nation implicit within them" (Turner, 1994b:33).

Whilst Khan's 'exploration' of Malay cinema is but a conceptual attempt at re-defining the sociocultural and political function of national cinema which belongs to a heterogeneous Malaysian society, the Australian cinema, however, has achieved more than just 'constructive' success in that regard. It has since been able to construct an important theoretical understanding of itself, as stated by Tom O'Regan in The Australian national cinema (1996:22): "Australian cinema is involved in charting existing and emergent social divisions and identities within society. It accommodates, recognizes and promotes the social divisions constitutive of society $[\ldots]$ and provide[s] for alternative [sic] even counter-identities and histories. There is a favouring of political understandings of Australia as a fractured polity over understandings of it as a people united by shared symbols and myths". O'Regan's theorizing is sublimely instructive of what Khan actually wants the Malay/sian cinema to achieve in both theory and practice. Interestingly, as a contrastive irony to O'Regan's work, Khan's theorizing of the Malay/sian cinema somewhat exposes its anachronistic tendency, possibly because its critical view could not be matched or substantiated by the problematics of a national film culture in the 1990s which was inadequately wanting in film policy and funding, thus affecting quantity, quality and diversity of Malay/sian films.

\section{Khan's Malay/sian Cinema: What Gives?}

Khan's theorizing begins by criticizing the prevailing state of early 1990s "Malaysian cinema" - instead of Malay cinema - "[which] despite technical improvements, still dwells on cliché-ridden basic structures and materials" (ibid.):

Popular songs are turned into flimsy story-lines; popular singers who know nothing about film acting are given leading roles; and trivial matters alike family quarrels and student falling in love with teachers are made into films. Social problems are seldom discussed at length. National tragedies and crises have never been exploited in Malaysian films, which is why too few films qualify to be considered as national cinema. The Hollywood tradition of story-telling through pictures, which has influenced both the Indian and Hong Kong mainstream cinemas, is still being used as the basic cinematic expression in Malaysian films (ibid.).

Besides suggesting commercial gains and business interests as the natural, 'bottom-line' practices in Malay film industry, Khan's criticism also exposes the narrowness if not meaninglessness of the narratives, including the apparent irrelevance of nationhood in nationalistic imaginary. With few exceptions, mainstream Malay filmmakers appear to have abstained themselves from cinematic 'discourses of nationalism' in feature or documentary filmmaking. Whether or not they have ever been 'a prisoner of conscience', as it were, other than 
being subjected to censorship laws, the worst kind of 'persecution' a film and the filmmaker could be facing is perhaps the "political' one. Khan himself has ruled out "political or radical" discourses in new Malay/sian cinema as the filmic appeal of a "cinema of opposition" (ibid.) playing to the gallery of socioculturally-diverse national audiences would be quite inconceivable and 'politically incorrect'.

Political consciousness and correctness for the majority of postcolonial Malaysian society have been 'mainstreamed' in the last fifty years under an elitist, conservative, Malay-Islamic hegemonic power structure. Unlike (say, Malaysian female) sexuality, however, it can be safely assumed that most Malaysian filmmakers acknowledged the wisdom of precluding Malay-Islamic discursive practices, unless they, like the 1960s filmmaker Hussein Haniff, have 'anti-establishment' statements to make through their work. Haniff and Ramlee were identified by Khan as the filmmakers who attempted to discuss common, serious issues in the Malay society "as subject matter" (189) during the studio days. As far as 'art for society' is concerned, Haniff's Hang Jebat is a rare but classic portrayal of social realism in Malaysian cinema, and it marks the emergence of Malay cinema as "a vehicle of political influence on the views and attitudes of the Malays" (189). It has been the only anti-heroic film version 'celebrating' Jebat and his raison d'etre - unlike the multiple 'reincarnation' of Tuah in other Malay films (Note 3) - for the simple reason that Malaysian filmmakers and the government-subsidized film industry do not want to be implicated with an anti-establishment agenda or view. In fact, it may be seen as defying the dominant historical and political assumption of the Malay hegemony when Phani Majumdar's Hang Tuah is alienated by Hussein Haniff's Hang Jebat as the preferred foundational text in his effort to conceptualize Malaysian cinema. Indeed, at another level of its social semiotics, it appears to be echoing for social justice for the common people, which seems to be the recurrent battle-cry for opposition parties (Note 4) and civil society movements struggling against political, economic and social injustices.

One suspects that Khan's thoughts on national cinema is partly shaped by the fact that Malay cinema has never attempted nor allowed itself to be the vehicle for sociocultural and political attitude and agent of change especially for the Malays in both colonial and postcolonial conditions. Besides the constraints imposed by censorship laws, which apparently, like the draconian laws of unlimited detention without trial, the Internal Security Act (ISA) originally introduced by and inherited from the British colonial government back in 1927 to delimit freedom of expression and creativity of the intellectuals, Malay cinema's business-as-usual attitude has kept out of the audience imagination from relating to quotidian issues that beset the diverse and pluralistic Malaysian lifeworlds long before they finally emerge in the works of latter-day generation of Malay filmmakers such as Yasmin Ahmad, Amir Muhammad, Afdlin Shauki and Mamat Khalid. In highlighting his misgivings for the apparent lacunae in Malay film history and film culture, Khan appears to be committing his critique towards a nationalistic paradigm as perhaps part of a larger concerted attempt by the film industry's players to fill the once-purposive gap in the genealogy of Malay film industry:

However the British rule in pre-war and post-war Malaya was hardly documented through Malay films. The British economic exploitation, the problems that they created by bringing in the Chinese and Indian immigrants (Roff 1980, 249), the fight against the communist terrorists and the struggle of the Malay nationalists could well have been explored for cinematic substance had the Malay film industry been more alert to the historical events during a period that spans more than a decade. But the industry choose $[\mathrm{sic}]$ to stay away from the political and social reality of a nation struggling to free itself from the colonial grip. Even after Malaysia was formed and the filmmaking activities shifted to Kuala Lumpur, the Malay film industry still moved in a lost direction, forgetting the history and aspirations of the nation and its people. It was only in the 1980s that Malay films in the hands of Malay independent companies tried to look at the nation's history for its subject-matter. (193)

Khan's confidence in a Malay cinema revival is founded on critical reception rather than box office figures of a handful of films produced in the 1980s and early 1990s by overseas-educated Malay filmmakers. These films depict significant events in the history of this nation-state which nevertheless reflect and sustain what are largely seen as the sentiments and interests of Moslem-Malay society and political establishment. The first example of such "Malaysian national cinema" (194) is Jins Shamsuddin's Bukit Kepong (1981), a film about the struggle of the Malayan security force against the terror of the Malayan Communist Party in February 1950, in Bukit Kepong, in the southern Malaysian state of Johor. Like Bukit Kepong, Kamarul Ariffin's Yassin (1988), which, "tells the story of a man who was tried by the Malayan People's Anti-Japanese Army or the Bintang Tiga, for allegedly helping the Japanese during the Pacific War" (213), in Khan's opinion, does capture the rare "esprit de corps of the Malayan society of different races during the last few days of the Japanese occupation in Malaya" (214). Earlier on, Kamarul produced Jasmin (1984), a film inspired by the Natrah incident and directed by the 
veteran filmmaker, Jamil Sulong. However, Jasmin's massive distortion of the historical facts of the Natrah case by sidestepping the racial and religious issues, and the Singapore riots that ensued following the 1950 British court ruling, is viewed by Khan as an example of a "national Malaysian film that failed [...] to deal directly with the momentous political issues raised by the actual historical event" (199).

Khan deploys the work of Syed Hussein Alatas (Note 5), an eminent Malaysian sociologist, to expose the root of corruption in Malaysia as essentially being the "marriage between business and politics" (202) which burgeoned under Mahathir's UMNO-led government. But if Khan feels that "national crisis like poverty, power abuse, corruption at the highest levels and national identity concerning attitudes, values and world views of the people are left untouched by filmmakers and producers" (ibid.), this is because Malaysian filmmakers are themselves directly or indirectly the beneficiaries of government political ideology and economic policies. This is perhaps why Khan does not have sufficient number of works to sample from in proposing and consolidating Malay cinema's 'sociocultural turn'. Shuhaimi Baba's Ringgit Kasorrga (High Society, 1995) is perhaps the first Malaysian film to treat the theme of systemic corruption among Malay businessmen and politicians within an imaginative and engaging narrative although she had to 'gloss' her film with top-rated 'stars' of the day. In fact, Shuhaimi's film has proven (to a sceptic like Khan) that such a theme "[can] become an interesting backdrop to Malaysian film storylines" (202).

Khan's study demonstrates that Malaysian film audience is divided along ethnic lines, with Chinese audience forming the biggest group of patrons of imported Western and Chinese films. It is more interesting to note that ten years after his 1994 study, Khan was able to witness perhaps the most fascinating dynamics in film spectatorship in Malaysia following the release of Yasmin's Sepet. In hindsight, Khan had noted that the non-Malays would stay away from Malay cinema especially if they were "pro-Malay and pro-Muslim" (209) such as Bukit Kepong and Yassin. Entrenched in the minds of Chinese and Indian audiences, as he had found out was that 'Malaysian cinema' was in actual fact this self-serving and parochial Malay cinema "dealing with the life and struggle of the Malays, projecting Malay values and customs, and is basically made by Malays for the Malays" (ibid.). Moreover, since Malay film audience being "99.9\% Malay" (ibid.), it is not surprising that Khan is rather suspicious about Malay/sian cinema's ability to transcend such prejudice because, as he claims to be the case, Malay filmmakers themselves "are not willing to test the market and create a precedent for a serious film that would attract the well-educated middle class Malaysian" (213).

\section{Cinema-of-intent 3: Anticipating the Sociocultural Turn}

The space between the inception of FINAS in 1981 and the conception of National Film Policy (NFP) (Note 6) in 2005 is almost twenty-five years. And one could suggest, in an O'Reganesque sense, that Khan's work filled the discursive void of the national imaginary by charting existing and emergent sociocultural discourses constitutive of the multiethnic society; accommodating, recognising and promoting that which should be reflected in Malay films. But one could also be sympathetic with Khan that his dreams may have been let down by the NFP's short-term strategies (Note 7) whereby, only one out of nine is dedicated at "producing film with Malaysian characteristics".

Whilst such policy and strategies may reflect, in the words of Geoffrey Nowell-Smith (in Higson 1989:38) "the recognition of popular forms as a legitimate part of national cultural life", they need to be connected to some philosophical touchstone in order to help Malay/sian filmmakers with creative direction during a transitional phase. This is where Khan's idea, nationalist yet progressive, becomes an important contributing germ for the dissemination of ideological transformation of Malay/sian cinema from its ethno-nationalist tendency towards a more inclusive, diverse and (idio)syncretic national cinema that can connect ordinary Malaysians with themselves and their everyday-defined social reality as found in the definitive works by discerning Malay filmmakers like Rahim Razali and Yasmin Ahmad two decades later. Khan's states his formulaic-like vision of an audience-centric, inward-looking national imaginary as follows:

[Malay/sian] [c]inema will have to give a true picture of the various ethnic groups, while at the same time maintaining a balance so as not to offend sensitivities about differing customs and religions. Sensitive issues will have to be examined in a positive manner in order to contribute towards national integrity and solidarity.

(Khan, 1996:49).

It is argued that embedded within such cursory and minimalist statements is the signal for Malay cinema to make a 'sociocultural turn' so that its almost 'exclusively' ethno-centric visuality can be reformed into a filmic space for articulating subjectivity across multiethnic Malaysian society. It is perhaps less than accurate to implicate Khan's 'sociocultural turn' with his penchant for cinematic realism, which he calls 'true picture'. As a matter of fact, Khan's 'true picture' is merely a modification to his main cinematic concern which is the representation of 
'the various ethnic groups' in the Malay-dominated film industry. Indeed, the visuality of the disenfranchised Other Malaysian in Malay cinema has been negligible.

\section{7. 'True Picture': Rooting for Social Realism}

It seems clearer now, after Khan's rather vague statement at the beginning of his "exploration of the Malay cinema as an example of 'National Cinema"' (1997:11), as to the ultimate direction of his discourse, which is to (re)claim the 'true picture' deserved by Malaysian audiences. This is reinforced by Khan's assertion that "[t]he main aim of a national cinema is to get the message across to the people, especially when the film-maker is trying to portray truthfully some events or situations or what is now being termed as social realism" (35). Verisimilitude is an important element for Khan's 'true picture' if the sociocultural and political realities of the everyday are to be represented "in the interests of knowledge and social justice" (Hallam and Marshment, 2000:xiii). Recalling Raymond Williams' (1977) interest in "the complex relationships between [...] artistic expression and their adequacy to describe social experience" (97), the co-authors Julia Hallam and Margaret Marshment point out that "realism has a political dimension that overrides technique: the bringing of hitherto neglected groups onto the screen, the speaking of previously unheard truths and unexpressed attitudes" (47). Khan's 'true picture' certainly suggests that the visualization of invisible and marginalized voices as key steps in recalibrating the social parameter of the national cinema beyond the plain parochialism of Malay cinema.

The socio-realist germs of Khan's 'true picture' can perhaps be traced back to the commentaries by James Monaco and David Hanan on the impact of social realism in the works of Andrzej Wajda and Teguh Karya respectively. Representing Polish cinema slogan since 1929 that "film must be socially useful" (32), Wajda's cinematic approach is "to tell the [film] audience something, to make people think, to initiate a dialogue" especially when "something is not correct, and therefore needs to be redressed" (ibid.). Monaco (in Khan, 1997:32) regards Wajda's film to be "dialectical", meaning, it is conceived "as an intellectual tool, a forum for examination and discussion" although he is skeptical knowing that film audience will be "waiting for [the] film to do all the work, to envelop them in the expected heady fantasies". Khan, however, dismisses Monaco's skepticism, claiming that Wajda's social realism "when properly understood, offers one of the most exciting possibilities for the future development of cinema" (Khan, 1997:32). Khan seems to subscribe to the practice of incorporating "politically and socially conscious ideas [sic] into films", which he argues is "being practiced by new wave directors all over the world"(ibid.).

The film philosophy of Karya, as Hanan (in Khan, 1997:37) has observed, is primarily about "the discourse of "representing one's own culture" which links his perspective of the "true task of a national cinema" (Khan, 1997:37) to a geoculturally-situated practice known as regionalism. Inherent in this form of social realism is the filmmaker's capacity "to have a certain stand regarding the values, customs and traditions of his people in contrast to foreign or imported culture" (ibid.). Based on the Indonesian cinema practices, Hanan argues that a national cinema should give due "recognition of the diversity, specificity and complexity of the many cultures as faithfully as possible and the portrayal of the traits and characteristics of these [regional] cultures [and societies]" (in Khan, 1997:36).

Malay filmmakers at large, however, appear to have some 'reservations' toward social realism, perhaps into making it as one of the national cinema's aesthetics and styles. The fact is that social realism used to be the prevalent aesthetics and style of Malay cinema. The consumption of social realism in Malay cinema perhaps achieved 'subliminal' reception through internationally-acclaimed film directed by P.Ramlee such as $I b u$ Mertua-ku (lit. My Mother-in-Law, 1962), a tragic portrayal of the fate of socially disadvantaged individual set against the hierarchical feudalistic Malay society; or Madu Tiga (lit. Three Wives, 1964), a comedic depiction of the notorious tendency among Malay men to use (read misuse) their religious rights to polygamy on the pretext of observing the tradition of Prophet Mohammed. The apparent 'reluctance' or 'hesitation' is perhaps self-explanatory given the predominance of commercialism in the mainstream film industry whose concern is more about its profit margin. But for Khan, this pessimism may perhaps be attributed to the lack of moral (or political) conviction to 'force' through social realism as a possible cinematic form or agenda.

\section{Conclusion}

It is argued that Khan's conviction in the potential of his kind of cinema-of-intent making inroad into the mainstream film industry resonates today with achievement of those who share the idealism of his 'true picture', though with varying degree of success and critical reception. Khan cautions those who opt for the easy picking, as it were: "[t]he most important thing for a film-maker is to be sincere in choosing the subject matter and not to leap at anything popular or trendy in order to capitalize on it and create something which looks pretentious and misleading" (Khan, 1997:187). Freedom of expression, corruption and poverty are considered by Khan as forms 
of a national crisis that should have long been the subject-matter of Malaysian filmmakers. He appears to be insinuating Malaysia's inherent crisis of integrity as "a tragedy for the people" but which "seldom appears in [Malaysian] films" because "there are too many things that cannot be discussed openly" (200) and "totally divorced from the reality of life" (203). This environment cannot be conducive for his 'true picture'.

The cinematic realism that Khan is seeking for is quite simply, a variety of social realism which is 'progressive' for the Malaysian sociocultural and political contexts. Lest misunderstood particularly by Malay cinema enthusiasts, the 'sociocultural turn' does not remove Malay cinema's cons/institutional birthright. Its impact on Malay cinema discourse, if any, is perhaps mitigated by the fact that this critique is derived 'from within' - in Khan being a Malay-Moslem critic - as oppose to someone from outside of the dominant cultural status quo. Implicit in Khan's 'sociocultural turn' is the assumption that the national film industry has 'forgotten' that social justice, rights to the freedom of expressions and equality of opportunity are core values of democracy inherent to the creative process of reconfiguring the 'true picture' of Malaysian national cinema identity.

\section{References}

Anderson, B. (1987). The imagined communities. Reflections on the origin and spread of nationalism. London \& New York: Verso.

Chakravarty, S. (2000). Fragmenting the nation. Images of terrorism in Indian popular cinema. In Hjort, M. \& Mackenzie, S. (Eds.), Cinema and nation (pp. 222-238, 2000). London \& New York: Routledge.

Dermody, S. \& Jacka, E. (1987). The screening of Australia. Vol. 1. Anatomy of a film industry. Sydney: Currency Press.

Higson, A. (1989). The concept of national cinema. Screen, 30(4), 36-47.

Higson, A. (2000). The limiting imagination of national cinema. In Hjort, M. and Mackenzie, S. (Eds.), Cinema and nation (pp. 63-74). London \& New York: Routledge.

Khan, H. A. (1997). The Malay cinema. Bangi: Penerbit UKM.

Rayner, J. (2000). Contemporary Australian cinema. An introduction. Manchester: Manchester University Press.

Turner, G. (1994a). The end of the national project? Australian cinema in the 1990s. In Dissanayake, W. (Ed.), Colonialism, nationalism in Asian cinema (pp. 202-216). Bloomington, Indianapolis: Indiana University Press.

Turner, G. (1994b). Whatever happened to national identity? Film and the nation in the 1990s. Metro Magazine, $100,32-33$.

Wark, M. (1995). Cinema II: the next hundred years. In Brookes, J. (Ed.), A century of Australian cinema (pp. 198-211). Port Melbourne, Victoria: Australian Film Institute and William Heinemann Australia.

Wayne, M. (2002). The politics of contemporary European cinema: Histories, borders, diasporas. Bristol: Intellect Books. Retrieved July 24, 2011, from: http://nickredfern.wordpress.com/category/brassed-off/

Willemen, P. (1992). The making of an African cinema. Transition, 58, 138-150. http://dx.doi.org/10.2307/2934972

Wimmer, A. (2007). Australian film. cultures, identities, texts. Trier: WVT, Wissenschaftlicher Verlag Trier. http://www.finas.gov.my/index.php?mod=finas\&sub=perutusan (August 25, 2011)

http://www.pogar.org/publications/other/constitutions/malaysia-e.pdf (July 23, 2011)

\section{Notes}

Note 1. The Baling Famine Protest rally was led by university students for the hardcore condition of poverty of Malay farmers in Baling, Kedah, resulting in the detention under the notorious Internal Security Act (ISA) of many protestors including its leader, Anwar Ibrahim, now the Malaysian Opposition leader in the Parliament.

Note 2. Article 153(1): "It shall be the responsibility of the Yang di-Pertuan Agong to safeguard the special position of the Malays and natives of any of the States of Sabah and Sarawak and the legitimate interests of other communities in accordance with the provisions of this Article." In http://www.pogar.org/publications/other/constitutions/malaysia-e.pdf 23/07/2011

Note 3. Since Ramlee starred as Hang Tuah in Phani Majumdar's Hang Tuah (1955), two other film versions of 'Tuah' have been made, namely, Tuah (1988) by Anwardi Jamil and The Princess of Mount Ledang (2004) by Saw Teong Hin. 
Note 4. 'Keadilan' is also the popular namesake of Parti Keadilan Rakyat (The National Justice Party) whose de facto leader is Anwar Ibrahim, former deputy Prime Minister of Malaysia and currently, leader of the Opposition in the Parliament. It is not sure if Hang Jebat is watchable on Malaysian television like the popular reruns of Ramlee's films considering the almost total censorship practised by government-controlled media since his sacking in 1998 including against political satires in songs, cartoon books, plays and films.

Note 5. Syed Hussein Alatas who wrote seminal works like The myth of the lazy native (1977) which informed Edward Said's Orientalism (1978); and Corruption: Its nature, causes and functions (1991), was once the founder-president of Gerakan, a component party of the ruling National Front coalition.

Note 6. The main aims of the National Film Policy are firstly, "to support the national film industry to be more progressive and internationally competitive"; and secondly "to be the catalyst for the industry development in making the country as filming destination in the region".

Note 7. The nine short-term strategies outlined in the NFP for 2005-2010 are: "Achieving awards at international festival; Participating in international film festival; Organizing Malaysia Film Week overseas; Making Malaysia as a film making hub; Providing funds and investments; Enhancing skill in film making; Producing at least twelve quality local films every year; Producing film with Malaysian characteristics; and, Luring international filming projects to Malaysia". 